UDC 02:[004.774:001.102]

KLYMENKO O. Z.

V. I. Vernadskyi National Library of Ukraine (Kyiv, Ukraine), e-mail: klimenko_oz@ ukr.net, ORCID 0000-0003-4821-8503

SOKUR O. L.

V. I. Vernadskyi National Library of Ukraine (Kyiv, Ukraine), e-mail: sokurol@ukr.net, ORCID 0000-0001-9861-3283

\title{
PARTNERSHIP AS AN EFFECTIVE FORM OF CONSOLIDATION AND INTEGRATION OF INFORMATION RESOURCES OF LIBRARIES OF UKRAINE
}

Objective. The report is aimed to represent library partnership as an important component of diversification interaction of domestic scientific libraries and a universal form of consolidation of digital resources of documentary heritage. Methods. The methodology of the article is based on the general scientific principles of systematization, complexity, comprehensiveness of knowledge. Results. The content of publications of Ukrainian scientists in recent years on the importance of library projects for the development of domestic librarianship is highlighted. The use of the term "library partnership" in library science is substantiated. The most successful projects of scientific libraries of Ukraine as modern multifunctional institutions are presented. Conclusions. Positive consequence of active interaction of libraries through partnership is the implementation of effective communication, overcoming industry and departmental separation, targeted activities on customer focus, expanding the range of new services, a qualitatively new level of information library space. Prospects for further development of the domestic scientific, educational and cultural space through the library partnership are outlined.

Keywords: scientific library; interaction of libraries; partnership; library project; V. I. Vernadskyi National Library of Ukraine

\section{Introduction}

The evolution of the entire system of scientific communications in the context of globalization of social processes has formed a new paradigm of interaction in the activities of libraries as a dyad of mutual exchange and mutual enrichment. The defining category of effective transformations and dynamic changes in modern library science and practice of Ukraine is the interaction of libraries, which optimizes traditional and represents innovative strategies, forms, types, models of forming an integrated library and information resource as an important component of global e-space.

Traditional and innovative solution of problems of modernization of domestic libraries requires the study of scientific-theoretical and practical aspects of library partnership as an important component of diversification of scientific libraries and universal technology of consolidation of digital resources of documentary heritage. This positively affects the quality of library and information services through the introduction of new e-services and the provision of unlimited Internet access to relevant information.

Thus, the study of the essence and content of the library partnership, identifying its potential opportunities in the formation of a consolidated electronic resource of cultural heritage, promotion of the achievements of Ukrainian culture and science are extremely relevant for successful progress of domestic library science and practice. 


\section{Methods}

The methodology of the article is based on the general scientific principles of systematization, complexity, comprehensiveness of knowledge. The use of general scientific (analysis, synthesis, generalization) and special research methods (comparative-historical, retrospective, problem-chronological) contributed to the achievement of this goal.

Analysis of recent research. Characterizing the available source base, it should be noted that most of the materials devoted to the interaction are mainly articles, dissertation research, reports, meeting reports, seminar and conference proceedings (Klymenko \& Sokur, 2019). Among the domestic scholars who in one aspect or another cover library interaction through partnership, it is worth mentioning the publications of T. Vylehzhanina (applied aspects of library cooperation) (Vylehzhanina, 2013), O. Voskoboinikova-Huzieva (social partnership as a factor in the development of library and information sphere of Ukraine) (Voskoboinikova-Huzieva, 2014), O. Klymenko (theoretical principles of interaction of scientific libraries) (Klymenko, 2016), O. Sokur (scientific and organizational support of interaction libraries of scientific institutions of the National Academy of Sciences of Ukraine) (Sokur, 2019), S. Shemaiev (conceptual principles of system interaction of libraries with museums and archives) (Shemaiev, 2016) and O. Rybachok (international projects on integration of digital resources of archives, libraries, museums) (Rybachok, 2018).

The participation of librarianship researchers (theorists and practitioners) in the scientific discourse makes it possible to join the search for ways to overcome the applied problems of the domestic library industry in today's conditions.

\section{Results and Discussion}

Libraries of Ukraine are a basic element of cultural, scientific, educational, information infrastructure of the state. Today, libraries are looking for new approaches to cooperation, the development of modern thinking, rapid response to major events. Libraries are becoming the channel through which more and more people from different social groups join the process of cooperation, here the public is consolidating on social issues, and this is very important for the development of partnership and the formation of civil society (Klymenko, 2016).

Trends in recent years have shown the dynamism of the transformation of information and communication activities of libraries and the shift of work priority focus in the electronic environment. The desire to work ahead of social demands and compete with other cultural and information institutions encourages the adaptation of all known components, including cooperation, collaboration, partnership, consolidation, which promotes library integration in general. The interaction of libraries as the basic documentary and information institutions of society, which have unique cultural and historical funds, requires the establishment and strengthening of productive information and cultural ties in order to form a single consolidated information space.

Interaction is an important factor in the integration of cultural and scientific heritage in a globalized world and is based on the conceptual foundations of the development of the global infrastructure of electronic science. The principles based on which libraries interact productively are partnership, openness and equality of the parties for the purpose of development and use of the integrated library and information resource to develop a full-fledged scientific and information space in Ukraine. A promising area for further development of the information service is the partnership between libraries. Any model of library development involves the active use of partnership, among its main types are sectoral partnership (library-library); intersectoral 
partnership (library and institutions of culture, science, education, business, public associations, creative unions, etc.); international partnership (sectoral and intersectoral); partnership with public authorities (legislative and executive branches), especially with ministries and departments that have libraries under their authority. The interaction of libraries of Ukraine is developing more and more actively, and the activity of partner libraries takes place without changing the legal status, staff schedule and additional financial costs. However, participation in corporate associations imposes some obligations on partners. First of all, it is the appropriate technical and technological support (Internet connection, available modern automated system, workstation arrangement). Secondly, compliance with current corporate rules (standards, instructions) and work completion in a timely manner (Sokur, 2019).

Monitoring of the professional information flow showed the constant development of the main subsystems of library interaction, in particular partnership to meet the information needs of society. The partnership is based on compliance of content, goals and results with the requirements of current international and national legislation, priority of common interests and goals over the interests of individual partners, equality of all partners within the partnership agreement, voluntary participation in the partnership.

Partnerships can be created for any period. According to the analysis of publications of domestic practice, they can be divided into short-term (from one day to a month and a half), limited (for several months) and permanent (those that occur from time to time over many years) (Suprunets, 2009). The short-term form of library partnership includes exhibitions, expositions, presentations, joint seminars, round tables, conferences, meetings, webinars, lectures, etc. Limited forms can be designed for a significant but well-defined period. As an example, the creation of a museum exhibition or the use of a grant, work on joint publication, acquisition. Permanent (situational) projects are relevant today, i.e. the creation of library societies and commissions, exchange of literature, preparation of bibliography, informing about new acquisitions on certain topics, methodological support of libraries.

As a relatively new phenomenon, the partnership in the domestic library science reflects the processes of expansion and complication of forms of interaction, which in essence is always mutually beneficial. Successful partnerships are fostered by the dominance of a strategy of cooperation and compromise through the formation of effective integration and cooperation ties. Today, in the context of growing regional budget deficits, domestic library partnership, in our opinion, is the most effective tool for modernizing the library industry and social infrastructure in general. Thus, partnerships in the domestic library services are, as a rule, in many cases multilateral cooperation of various institutions and organizations, such as museums, archives, higher education institutions for the development of the Ukrainian European state.

In the face of such negative factors as limited funding, unsatisfactory logistics and staff shortages, participation in library projects is essential for the development of domestic libraries in cultural, scientific, educational and information infrastructure, which will also result in the implementation of an effective communication policy, overcoming sectoral and departmental separation, purposeful effective customer orientation, introduction of new services, productive formation of information and library space at a qualitatively new level.

For the successful formation of an integrated scientific information space, the development of such national scientific information projects is of undeniable importance, the main coordinator of which is the V. I. Vernadskyi National Library of Ukraine: abstract database "Scientific Ukraine", electronic library of professional periodicals "Scientific Periodicals of Ukraine", electronic library "Ukrainika", information portal "Science of Ukraine: Access to Knowledge".

Implementation of projects on a national scale contributes to strengthening the information base of innovation and support of reform processes in the country, the connection of national 
information resources to the international system of scientific electronic communications, which contributes to the formation of a positive image of Ukrainian science.

Each collaborating party contributes to the joint project. One of the technologies widely used in the practice of partnership in the domestic library science is the creation of electronic libraries. In the library and information space, scientific electronic libraries should become separate system-forming elements that perform information and communication functions in the status of an independent resource, as well as are part of the combined resources of general scientific importance. For example, the participants (only 111 today) of the integrated resource electronic library "Culture of Ukraine" are national libraries (among foreign ones is the National Academic Library of Republic Kazakhstan), libraries of Ukrainian universities, all domestic regional universal scientific libraries, research institutions, publishers, authors, etc. Together they gave one of the most popular contents of relevant information on the history of Ukrainian culture.

An example of a successful partnership is also the project "Catalogs of Libraries of Institutions of the National Academy of Sciences of Ukraine" launched in the V. I. Vernadskyi National Library of Ukraine (about 30 libraries of scientific institutions of the National Academy of Sciences of Ukraine are its active participants). Work is underway to involve network libraries in the creation and maintenance of an electronic catalog on the server of the V. I. Vernadskyi National Library of Ukraine, which requires methodological support, systematic organization and training "Corporate Cataloging: New Technologies and Opportunities for Academic Libraries". Seminars are held for the heads of libraries of scientific institutions, which cover the issues of bibliographic recording into the electronic catalog, entering descriptions of book memorabilia, creating authoritative files of the names of persons and institutions, features of systematization of scientific publications, etc.

\section{Conclusions}

The analysis carried out in the article allows to state that library partnership as a universal and most effective library resources consolidation technology is: 1) an important component of diversification interaction of modern scientific libraries, which promotes formation of consolidated domestic scientific-cultural-educational space; 2) an incentive for library integration into the world's common information space through digital resources of documentary heritage; 3 ) establishing and strengthening of productive information and communication links of libraries that have unique cultural and historical funds; 4) introduction of modern information and communication technologies, system optimization and modernization of all areas of multifunctional activity. Interaction through partnership encourages research libraries, as the basic documentary and information institutions of society, to work ahead of social demands and compete with other cultural and information institutions in the context of digitalization through the implementation of creative library projects.

We see the prospect of further research in the development of history studies, stages of creation, development strategies of both domestic and foreign library partnerships; launch of scientific research of theoretical, methodological, organizational, and legal principles of partnership; substantiation of its actual traditional and innovative forms and types. After all, despite the wide range of library research in recent years in this area, the library partnership, in our opinion, needs further specification of the term. The issue of classification and typology of library projects remains relevant and it is necessary to study and introduce into domestic practice the best foreign experience of library projects in the context of global digitalization. 


\title{
REFERENCES
}

Klymenko, O. Z. (2016). Recognize the Ukrainian language library in the informational suspension. Naukovi pratsi Natsionalnoi biblioteky Ukrainy imeni V. I. Vernadskoho, 44, 7-19. Retrieved from http://nbuv.gov.ua/UJRN/npnbuimviv_2016_44_3 (in Ukrainian)

Klymenko, O., \& Sokur, O. (2019). Aspectualization of interaction of scientific libraries in the conditions of formation of the national integrated resource (on materials of professional periodicals). Naukovi pratsi Natsionalnoi biblioteky Ukrainy imeni V. I. Vernadskoho, 56, 121-134. doi: https://doi.org/10.15407/np.56.121 (in Ukrainian)

Rybachok, O. M. (2018). International Integrated Digital Resources for the Documentary Heritage of Archives, Libraries, Museums: Stages of Creation, Development Strategies (80s XX - 10s XXI Centuries). (PhD dissertation). V. I. Vernadskyi National Library of Ukraine, Kyiv. Retrieved from http://nbuv.gov.ua/sites/default/files/disser/dis_1.pdf (in Ukrainian)

Sokur, O. L. (2019). Cooperation of Libraries of Scientific Institutions of the National Academy of Sciences of Ukraine in the Formation of the National Scientific Information Space: Scientific and Organizational Support. (PhD dissertation). V. I. Vernadskyi National Library of Ukraine, Kyiv. Retrieved from http://nbuv.gov.ua/sites/default/files/disser/dis_23.pdf (in Ukrainian)

Shemaiev, S. O. (2016). Collaboration between libraries, museums, archives in communication space of Ukraine. (PhD dissertation). Kharkiv State Academy of Culture, Kharkiv. Retrieved from https://ic.ac.kharkov.ua/nauk_rob/specrada/specrada/old_2017/Shemaev/disShemaev.pdf (in Ukrainian)

Suprunets, N . P. (Ed.). (2009). Social partnership: a new impetus for the development of public libraries. Retrieved from https://shag.com.ua/socialene-partnerstvo-novij-impules-rozvitku-publichnihbiblio.html (in Ukrainian)

Voskoboinikova-Huzieva, O. (2014). Cooperation as a means of successful functioning of libraries in the information environment. Bibliotechnyi visnyk, 4, 3-8. Retrieved from http://nbuv.gov.ua/UJRN/bv $2014 \quad 4 \quad 3$ (in Ukrainian)

Vylehzhanina, T. (2013). Social partnership as a factor in the development of the library and information sphere of Ukraine. Bibliotechna planeta, 4, 4-7. Retrieved from http://profy.nlu.org.ua/file/lp62.pdf (in Ukrainian)

КЛИМЕНКО О. 3.

Національна бібліотека України імені В. І. Вернадського (Київ, Україна), e-mail klimenko_oz@ukr.net, ORCID 0000-0003-4821-8503

СОКУР О. Л.

Національна бібліотека України імені В. І. Вернадського (Київ, Україна), e-mailsokurol@ukr.net, ORCID 0000-0001-9861-3283

\section{ПАРТНЕРСТВО - ЕФЕКТИВНА ФОРМА КОНСОЛІДАЦІЇ ТА ІНТЕГРАЦІЇ ІНФОРМАЦІЙНИХ РЕСУРСІВ БІБЛІОТЕК УКРАЇНИ}

\begin{abstract}
Мета. Репрезентувати бібліотечне партнерство як важливу складову диверсифікаційної взаємодії вітчизняних наукових бібліотек та універсальну форму консолідації цифрових ресурсів документальної спадщини. Методика. Методологія статті базувалася на загальнонаукових принципах системності, комплексності, усебічності пізнання. Результати. Висвітлено зміст публікацій українських науковців останніх років щодо значення бібліотечних проєктів для розвитку вітчизняної бібліотечної справи. Обгрунтовано вживання у бібліотекознавстві терміна «бібліотечне партнерство». Представлено найуспішніші проєкти наукових бібліотек України як сучасних мультифункціональних установ. Висновки.
\end{abstract}


Позитивним наслідком активної взаємодії бібліотек через партнерство є здійснення ефективної комунікації, подолання галузевого та відомчого відокремлення, цілеспрямована діяльність на клієнтоорієнтованість, розширення спектра нових сервісів і послуг, якісно новий рівень формування інформаційного бібліотечного простору. Окреслено перспективи подальшої розбудови вітчизняного науково-освітньо-культурного простору через бібліотечне партнерство.

Ключові слова: наукова бібліотека; взаємодія бібліотек; партнерство; бібліотечний проєкт; Національна бібліотека України імені В. І. Вернадського 